\title{
Bir Üniversite Hastanesindeki Aile Hekimliği Poliklinik Hastalarının Sağlık Okuryazarlık Düzeyleri ve İlişkili Etkenler*
}

\author{
Health Literacy Levels of Family Medicine Outpatients in a University Hospital and Related Factors \\ Nilüfer Emrei, Mehmet Arslanii, Tamer Edirne iii, Aysun Özşahiniv, Aylin Çiğdem ${ }^{\mathrm{i}}$ \\ 'Dr. Öğr. Üyesi, Pamukkale Üniversitesi Tıp Fakültesi Aile Hekimliği AD., https://orcid.org/0000-0002-6519-0920 \\ iiDr. Öğr. Üyesi, Pamukkale Üniversitesi Tıp Fakültesi Aile Hekimliği AD.,https://orcid.org/0000-0003-2791-4622 \\ iiiProf. Dr., Pamukkale Üniversitesi Tıp Fakültesi Aile Hekimliği AD., https://orcid.org/0000-0001-9683-5624 \\ ivDoç. Dr., Pamukkale Üniversitesi Tıp Fakültesi Aile Hekimliği AD., https://orcid.org/0000-0002-5768-4146 \\ varş. Gör. Dr., Pamukkale Üniversitesi Tıp Fakültesi Aile Hekimliği AD.,https://orcid.org/0000-0003-4026-8282
}

öz

\begin{abstract}
Amaç: Çalışmada, aile hekimliği polikliniğine başvuran hastaların sağlık okuryazarlığı seviyelerini ve etkileyen durumları değerlendirmek planlanmıştır.

Yöntem: Bu tanımlayıcı-kesitsel çalışma Mart-Haziran 2020 arasında gerçekleştirildi. Çalışma grubunu, Pamukkale Üniversitesi Tıp Fakültesi aile hekimliği polikliniğine başvuran 18 yaşüstü, okuryazar, iletişim kurulabilen ve çalışmaya katılmaya onay veren kişiler oluşturmaktadır. Anket formu 15 soruluk demografik özellikler ile sağlık okuryazarlığını değerlendirmek için Türkiye Sağlık Okuryazarlığı Ölçeği-32'den oluşmaktadır.

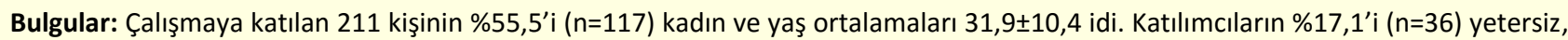
\%28,9'u (n=61) ise sorunlu-sınırlı sağlık okuryazarlığına sahipti. Yetersiz sağlık okuryazarlık düzeyi lise altı eğitimi olanlarda, evlilerde, fazla kilolu ve obezlerde anlamlı olarak daha yüksek saptandı ( ırasıyla $p=0,003 ; p=0,011 ; p=0,042$ ). Sağlık okuryazarlık ortalama puanı ve alt grup puanlarında ile yaş ve beden kitle indeksi (BKi) arasında negatif yönde zayıf düzeyde ilişki bulundu (sağlık okuryazarlık toplam puanı sırasıyla $r=-0,291 p=<0,001 ; r=-0,194 p=0,005)$.

Sonuç: Sağlık okuryazarlık düzeyi medeni durum, eğitim durumu, BKi düzeyinden etkilenmekteydi. Ayrıca genç yaş grubu ve düşük BKi ile sağlık okuryazarlık ortalama puanı ve alt grup puanları ilişkiliydi.
\end{abstract}

Anahtar Kelimeler: Sağlık okuryazarlığı, Aile hekimliği, Hastalar, Türkiye Sağlık Okuryazarlık Ölçeği

\section{ABSTRACT}

Objective: In the study, it was planned to evaluate the health literacy levels of patients who applied to the family medicine outpatient clinic and the affecting conditions.

Methods: This descriptive-cross-sectional study was performed between March and June 2020. The study group consists of individuals over the age of 18 who applied to the Pamukkale University faculty of medicine, family medicine outpatient clinic, who are literate, able to communicate and persons who consented to participate in the study. The questionnaire form consists of 15question on demographic characteristics and Turkey Health Literacy Scale-32 to evaluate health literacy. Results: Of the 211 people participating in the study, 55.5\% $(n=117)$ were women and their mean age was $31.9 \pm 10.4 .17 .1 \%(n=$ 36) of the participants had insufficient and $28.9 \%(n=61)$ had problematic/limited health literacy. Insufficient health literacy level was found to be significantly higher in those with less than high school education, married, overweight and obese $(p=0.003 ; p=$ $0.011 ; p=0.042$, respectively). A weak negative correlation was found between health literacy mean score and subgroup scores and age and body mass index (BMI) (health literacy total score, respectively, $r=-0.291 p=<0.001 ; r=-0.194 p=0.005$ ). Conclusion: Health literacy level was affected by marital status, educational status, and BMI level. Additionally, the young age group and low BMI were correlated with the mean health literacy score and subgroup scores.

Keywords: Health Literacy, Primary Health Care, Patients, Turkish Health Literacy Scale

\footnotetext{
${ }^{*}$ Mersin Üniversitesi Tıp Fakültesi Lokman Hekim Tıp Tarihi ve Folklorik Tıp Dergisi, 2021; 11 (3): $588-595$ DOI: $10.31020 /$ mutftd.943953

e-ISSN: 1309-8004, ISSN 1309-761X

Geliş Tarihi - Received: 27 Mayıs 2021; Kabul Tarihi - Accepted: 13 Ağustos 2021

iletişim - Correspondence Author: Nilüfer Emre < nilemre83@gmail.com >

Etik Kurul Onayı: Pamukkale Üniversitesi Tıp Fakültesi Girişimsel Olmayan Klinik Araştırmalar Etik Kurulu (Karar tarihi sayı: 17/03/2020 - 06).
} 


\section{Giriş}

Sağlık okuryazarlığı (SOY), uygun sağlık kararlarının alınması için önemli olan başlıca sağlık bilgi ve hizmetlerini edinme ve anlama becerisini edinme seviyesi olarak tanımlanmaktadır. ${ }^{1}$ Dünya sağlık örgütüne göre; sağlık okuryazarlığı, bireysel hayat tarzları ve şartlarını değiştirerek, birey ve halk sağlığını geliştirmek için belirli bir bilgi, şahsi maharet ve itimat seviyesine erişilmesi anlamına gelir. Bu sebeple, sağlık okuryazarlığı broşür okuyabilmekten ve randevu alabilmekten daha fazlasıdır. İnsanların sağlık bilgilerine erişimini ve bunları uygun olarak kullanma kapasitelerini geliştirmek, kişilerin sağlık okuryazarlığını güçlendirmede kritik bir role sahiptir. $^{2}$

Sağlık okuryazarlığı düzeyi toplumlar arasında farklılıklar göstermektedir. Avrupa'da yapılan bir çalışma, her 10 Avrupalıdan en az birinin sağlık okuryazarlığı düzeyinin yetersiz olduğu dahası ABD'de, kamu sağık tesislerinde tedavi edilen hastaların üçte birinin yetersiz sağlık okuryazarlığına sahip olduğu belirtilmektedir. ${ }^{3}$ Ülkemizde ise "Türkiye Sağlık Okuryazarlığı Düzeyi" araştırmasında tahmini 10 kişiden yedisinin sağılık okuryazarlığı düzeyinin düşük olduğu belirtilmektedir. ${ }^{4}$ Ayrıca SOY'un çeşitli sosyoekonomik değişkenlerden (kişilerin sağlık güvence durumu, gelirin hane halkı ihtiyaçlarını karşılama yeterliliği gibi) etkilenen hem de sağlığı ve sağlık hizmetlerini etkileyen bir durum olduğu belirtilmektedir. ${ }^{4}$

Literatürde düşük düzeyde sağlık okuryazarlığına sahip kişilerin, genellikle genel sağlık durumunun daha kötü olduğu bildirilmektedir. ${ }^{5}$ Bunun nedeni, düşük gelir ve zor yaşam ortamları yanı sıra sağlıklarını iyileştirebilecekleri yollar hakkında daha az bilgi sahibidirler ve tarama programları gibi hayat kurtaran olanaklardan yararlanma olasılıkları daha düşüktür. ${ }^{5}$ Bununla birlikte sağlık çalışanları, düşük sağlık okuryazarlığının azaltılmasında önemli bir role sahiptirler. Sağlık sisteminin ilk temas noktası olan yaş, cinsiyet ve rahatsızlık ayrımı yapmaksızın tıbbi bakım arayan her bireye sağık hizmeti ve koruyucu hekimlik hizmeti sunan aile hekimliğinde, sağlık okuryazarlı̆̆ı etkili hasta hekim ilişkisinin oluşmasında önemli etmenlerdendir. Buradan yola çıkarak öncelikle SOY düzeyi açısından durum tespitinin yapılması, sonra SOY'u geliştirecek stratejiler oluşturulması gerekmektedir. ${ }^{6}$ Çalışmamızda bir üniversite hastanesindeki aile hekimliği polikliniğine gelen hastaların sağlık okuryazarlığı seviyelerini tespit etmek ve SOY'u etkileyen durumları araştırmak ve ayrıca SOY'un geliştirilmesi çalışmaları için katkı sağlamak amaçlanmıştır.

\section{Gereç ve Yöntem}

\section{Araştırmanın Şekli}

Çalışma tanımlayıcı kesitsel olarak tasarlandı.

\section{Araştırmanın yapıldığı yer, tarih, örneklem}

Çalışma Pamukkale Üniversitesi Tıp Fakültesi Aile hekimliği polikliniğine Mart 2020-Haziran 2020 tarihleri arasında başvuran 18 yaş üstü, okuryazar, Türkçe bilen, iletişim kurulabilen ve çalışma için sözlü onam veren tüm hastalardan oluşmaktadır.

\section{Veri Toplama Araçları}

1- Anket formu: Yaş, cinsiyet, medeni durum, ailenin aylık geliri, yaşadığı bölge, eğitim durumu, boy, vücut ağırlığı, meslek, sosyal güvence, kronik hastalık tanısı, sigara kullanma durumu, egzersiz yapma durumu, herhangi bir sağlık sorununda ilk başvuru yeri, son bir yıl içinde sağlık kuruluşlarına başvuru sıklığını sorgulayan 14 soruluk demografik özelliklerden oluşan anket formu.

2- Türkiye Sağlık Okuryazarlığı Ölçeği-32 (TSOY-32): Okyay ve arkadaşları tarafından 2016 yılında HLS-EU çalışması temel alınarak oluşturulmuştur. 32 sorudan oluşan ölçek, iki temel boyut (Tedavi/hizmet ve Hastalıklardan korunma/sağlığın geliştirilmesi) ve dört bileşenden (Sağılıkla ilgili bilgiye ulaşma, sağlıkla ilgili 
bilgiyi anlama, sağlıkla ilgili bilgiyi değerlendirme, Sağlıkla ilgili bilgiyi kullanma/uygulama) oluşmaktadır. Ölçeğin puanlamasına göre; 0-25 puan yetersiz sağlık okuryazarlığı, >25-33 puan sorunlu - sınırlı sağlık okuryazarlığı, >33-42 puan yeterli sağlık okuryazarlığı ve >42-50 puan mükemmel sağlık okuryazarlığı olarak tanımlanmaktadır. ${ }^{7}$

\section{Araştırmanın Etik Boyutu}

Çalışma için; kişilerin sözlü onamı ve Pamukkale Üniversitesi Tıp Fakültesi Girişimsel Olmayan Klinik Araştırmalar Etik Kurulu'ndan izin alınmıştır (Karar tarihi - sayı: 17/03/2020 - 06).

\section{İstatistiksel analiz}

Çalışmamızdaki veriler sayı ve yüzde, ortalama \pm standart sapma olarak verildi. Ayrıca veriler için MannWhitney $U$ testi ve Ki-kare analizleri kullanıldı. Buna ilaveten sürekli değişkenlerin arasındaki ilişkiler Spearman korelasyon analizi ile değerlendirildi. İstatistiksel anlamlılı düzeyi $p<0,05$ olarak alındı. Veriler bilgisayar programında analiz edildi.

\section{Bulgular}

Çalışmaya katılan 211 kişinin \%55,5'i ( $n=117$ ) kadın, yaş ortalamaları 31,9 910,4 ve \%50,7'si (107) beden kitle indeksi açısından zayıf ve normal kilolu grupta yer almaktaydı. Herhangi bir sağlık problemlerinde ilk başvuru yerleri açısından \%30,3'ü ( $n=64)$ aile sağlığı merkezine, \%57,3'ü ( $n=121)$ hastanelere, \%12,3'ü ( $n=26)$ acil servise başvurmaktaydı. Katılımcıların \%17,1'i $(n=36)$ yetersiz, \%28,9'u $(n=61)$ sorunlu-sınırlı, \%28,4'ü ( $n=60)$ yeterli, \%25,6'sı (n=56) mükemmel sağlık okuryazarlığı düzeyine sahipti (Tablo 1).

Tablo 1. Katılımcıların demografik özellikleri

\begin{tabular}{|c|c|c|}
\hline & $\mathbf{n}$ & $\%$ \\
\hline \multicolumn{3}{|l|}{ Cinsiyet } \\
\hline Kadın & 117 & 55,5 \\
\hline Erkek & 94 & 44,5 \\
\hline \multicolumn{3}{|l|}{ Medeni durum } \\
\hline Evli & 111 & 52,6 \\
\hline Bekar & 100 & 47,4 \\
\hline \multicolumn{3}{|l|}{ Eğitim durumu } \\
\hline Lise altı & 47 & 23,3 \\
\hline Lise ve üzeri & 164 & 77,7 \\
\hline \multicolumn{3}{|l|}{ Gelir durumu } \\
\hline Gelir giderinden az & 59 & 28,0 \\
\hline Geliri giderine denk & 119 & 56,4 \\
\hline Geliri giderinden fazla & 33 & 15,6 \\
\hline \multicolumn{3}{|l|}{ Yaşadığı yer } \\
\hline Kırsal & 49 & 23,2 \\
\hline Kentsel & 162 & 76,8 \\
\hline \multicolumn{3}{|l|}{ Kronik hastalık } \\
\hline Evet & 41 & 19,4 \\
\hline Hayır & 170 & 80,6 \\
\hline \multicolumn{3}{|l|}{ Sigara içme } \\
\hline Evet & 69 & 32,7 \\
\hline Hayır & 142 & 67,3 \\
\hline \multicolumn{3}{|l|}{ ilk başvruru yeri } \\
\hline Aile sağlığı merkezi & 64 & 30,3 \\
\hline Hastaneler & 121 & 57,3 \\
\hline Acil servis & 26 & 12,3 \\
\hline \multicolumn{3}{|c|}{ Sağlık okuryazarlığı düzeyi } \\
\hline Yetersiz & 36 & 17,1 \\
\hline Sorunlu-sınırlı & 61 & 28,9 \\
\hline Yeterli & 60 & 28,4 \\
\hline Mükemmel & 56 & 25,6 \\
\hline
\end{tabular}


Katılımcıların demografik özellikleri ile sağlık okuryazarlık düzeyleri karşılaştııılığında; evlilerin, lise altı eğitimi olanların, fazla kilolu ve obezlerin yetersiz sağlık okuryazarlık düzeyleri istatistiksel anlamlı olarak daha yüksek bulundu (sırasıyla $p=0,011 ; p=0,003 ; p=0,042$ ). Tablo 2 'de demografik özellikler ile SOY düzeyleri gösterilmiştir.

Tablo 2. Demografik verilere göre sağlık okuryazarlığı düzeyi

\begin{tabular}{|c|c|c|c|c|c|c|c|c|c|c|}
\hline \multirow{3}{*}{$\begin{array}{l}\text { Demografik } \\
\text { özellikler }\end{array}$} & \multicolumn{8}{|c|}{ Sağlık okuryazarlığı düzeyi } & \multicolumn{2}{|c|}{ İstatiksel analiz } \\
\hline & \multicolumn{2}{|c|}{ Yetersiz } & \multicolumn{2}{|c|}{ Sorunlu-sınırlı } & \multicolumn{2}{|c|}{ Yeterli } & \multicolumn{2}{|c|}{ Mükemmel } & \multirow[b]{2}{*}{$x^{2}$} & \multirow[b]{2}{*}{ p } \\
\hline & $\mathrm{n}$ & $\%$ & $\mathrm{n}$ & $\%$ & $\mathrm{n}$ & $\%$ & $\mathbf{n}$ & $\%$ & & \\
\hline \multicolumn{11}{|l|}{ Cinsiyet } \\
\hline Erkek & 20 & 21,3 & 28 & 29,8 & 28 & 29,8 & 18 & 19,1 & \multirow{3}{*}{4,66} & \multirow[b]{2}{*}{0,198} \\
\hline Kadın & 16 & 13,7 & 33 & 28,2 & 32 & 27,4 & 36 & 30,8 & & \\
\hline \multicolumn{10}{|l|}{ Beden kitle İndeksi } & \\
\hline Zayıf-normal & 13 & 12,1 & 32 & 29,9 & 27 & 25,2 & 35 & 32,7 & \multirow[b]{2}{*}{8,22} & \multirow[b]{2}{*}{$0,042^{*}$} \\
\hline Fazla kilolu-obez & 23 & 22,1 & 29 & 27,9 & 33 & 31,7 & 19 & 18,3 & & \\
\hline \multicolumn{11}{|l|}{ Medeni durum } \\
\hline Evli & 23 & 20,7 & 40 & 36,0 & 26 & 23,4 & 22 & 19,8 & \multirow{3}{*}{11,07} & \multirow[b]{2}{*}{$0,011 *$} \\
\hline Bekar & 13 & 13,0 & 21 & 21,0 & 34 & 34,0 & 32 & 32 & & \\
\hline \multicolumn{10}{|l|}{ Eğitim } & \\
\hline Lise altı & 13 & 27,7 & 19 & 40,4 & 11 & 23,4 & 4 & 8,5 & \multirow{3}{*}{14,18} & \multirow[b]{2}{*}{$0,003 * *$} \\
\hline Lise ve üzeri & 23 & 14,0 & 42 & 25,6 & 49 & 29,9 & 50 & 30,5 & & \\
\hline \multicolumn{10}{|l|}{ Yaşadığı yer } & \\
\hline Kırsal & 8 & 16,3 & 15 & 30,6 & 13 & 26,5 & 13 & 26,5 & \multirow{3}{*}{0,18} & \multirow[b]{2}{*}{0,980} \\
\hline Kentsel & 28 & 17,3 & 46 & 28,4 & 47 & 29,0 & 41 & 25,3 & & \\
\hline \multicolumn{10}{|l|}{ Kronik hastalık } & \\
\hline Var & 12 & 29,3 & 10 & 24,4 & 12 & 29,3 & 7 & 17,1 & \multirow{3}{*}{6,25} & \multirow[b]{2}{*}{0,100} \\
\hline Yok & 24 & 14,1 & 51 & 30,0 & 48 & 28,2 & 47 & 26,4 & & \\
\hline \multicolumn{10}{|l|}{ Sigara } & \\
\hline Evet & 11 & 15,9 & 21 & 30,4 & 19 & 27,5 & 18 & 26,1 & & \\
\hline Hayır & 25 & 17,6 & 40 & 28,2 & 41 & 28,9 & 36 & 25,4 & 0,19 & 0,978 \\
\hline İlk başvuru noktası & & & & & & & & & & \\
\hline Aile sağlığı merkezi & 10 & 15,6 & 24 & 37,5 & 17 & 26,6 & 13 & 20,3 & & \\
\hline Hastaneler & 20 & 16,5 & 29 & 24,0 & 38 & 31,4 & 34 & 28,1 & & \\
\hline Acil servis & 6 & 23,1 & 8 & 30,8 & 5 & 19,2 & 7 & 26,9 & 5,57 & 0,472 \\
\hline Egzersiz & & & & & & & & & & \\
\hline Yeterli & 6 & 12,2 & 14 & 28,6 & 15 & 30,6 & 14 & 28,6 & & \\
\hline Yetersiz & 30 & 18,5 & 47 & 29,0 & 45 & 27,8 & 40 & 24,7 & 1,19 & 0,753 \\
\hline
\end{tabular}

TSOY-32 toplam puan ortalaması ile demografik özellikler incelendiğinde, kadınlarda, zayıf ve normal kilolu olanlarda, bekarlarda, lise ve üzeri eğitimi olanlarda ve kronik hastalık tanısı olmayanlarda, toplam puan ortalaması istatistiksel açıdan anlamlı olarak yüksek saptandı (sırasıyla $p=0,048 ; p=0,015 ; p=0,003 ; p=0,001$; $p=0,021 ; p=0,035$ ) (Tablo 3). Ayrıca kadınların hastalıklardan korunma ve sağlığın geliştirilmesi ile ilgili bilgiye ulaşma, bilgiyi anlama ve bilgiyi uygulama erkeklerden daha yüksekti (sırasıyla $p=0,007 p=0,015 p=0,021$ ). Zayıf ve normal kiloluların ise hastalıklardan korunma ve sağlığın geliştirilmesi ile ilgili bilgiye ulaşma, bilgiyi anlama, bilgiyi değerlendirme ve bilgiyi uygulama fazla kilolu ve obezlerden anlamlı oranda yüksekti (sırasıyla $p=0,003 p=0,005 p=0,043 p=0,014)$. Yine kronik hastalık tanısı olmayanların hastalıklardan korunma ve sağlığın geliştirilmesi ile ilgili bilgiyi anlama, bilgiyi değerlendirme ve bilgiyi uygulamada kronik hastalık tanısı olanlardan daha yüksek bulundu (sırasıyla $p=0,038 ; p=0,012 ; p=0,020$ ). 
Tablo 3. Demografik özelliklere göre sağıık okuryazarlığı puanları

\begin{tabular}{|c|c|c|c|c|c|c|}
\hline \multirow[b]{2}{*}{$\begin{array}{l}\text { Demografik } \\
\text { özellikler }\end{array}$} & \multicolumn{2}{|c|}{ Tedavi ve hizmet alt grup puanı } & \multicolumn{2}{|c|}{$\begin{array}{l}\text { Hastalıklardan korunma/sağlığın } \\
\text { geliştirilmesi alt grup puanı }\end{array}$} & \multicolumn{2}{|c|}{ Toplam sağlık okuryazarlık puanı } \\
\hline & Mean士SD & $Z / p$ & Mean $\pm S D$ & $Z / p$ & Mean $\pm S D$ & $z / p$ \\
\hline \multicolumn{7}{|l|}{ Cinsiyet } \\
\hline Kadın & $36,67 \pm 7,91$ & $-1,351$ & $34,54 \pm 10,78$ & $-2,238$ & $35,59 \pm 8,97$ & $-1,979$ \\
\hline Erkek & $34,77 \pm 8,56$ & 0,177 & $30,96 \pm 10,70$ & $0,025^{*}$ & $32,76 \pm 9,23$ & $0,048^{*}$ \\
\hline \multicolumn{7}{|l|}{ Beden kitle İndeksi } \\
\hline Normal-zayıf & $37,07 \pm 7,93$ & $-1,966$ & $34,92 \pm 11,05$ & $-2,573$ & $35,93 \pm 9,15$ & $-2,431$ \\
\hline Fazla kilolu-obez & $34,54 \pm 8,40$ & $0,049 *$ & $30,90 \pm 10,33$ & $0,010^{*}$ & $32,68 \pm 8,95$ & $0,015^{*}$ \\
\hline \multicolumn{7}{|l|}{ Medeni durum } \\
\hline Evli & $34,45 \pm 8,23$ & $-2,571$ & $31,09 \pm 10,78$ & $-2,787$ & $32,72 \pm 9,05$ & $-2,967$ \\
\hline Bekar & $37,34 \pm 8,03$ & $0,010^{*}$ & $35,01 \pm 10,64$ & $0,005^{* *}$ & $36,11 \pm 9,03$ & $0,003 * *$ \\
\hline \multicolumn{7}{|l|}{ Eğitim durumu } \\
\hline Lise altı & $30,98 \pm 8,02$ & $-4,371$ & $28,43 \pm 10,17$ & $-3,001$ & $29,54 \pm 8,65$ & $-3,890$ \\
\hline Lise ve üzeri & $37,21 \pm 7,79$ & $<0,001 * * *$ & $34,24 \pm 10,74$ & $0,003 * *$ & $35,70 \pm 8,88$ & $<0,001 * * *$ \\
\hline \multicolumn{7}{|l|}{ Gelir durumu } \\
\hline Asgari ücret altı & $36,25 \pm 8,24$ & $-0,286$ & $33,66 \pm 11,17$ & $-0,304$ & $34,02 \pm 10,38$ & $-0,030$ \\
\hline Asgari ücret üzeri & $36,10 \pm 7,68$ & 0,775 & $34,12 \pm 9,71$ & 0,761 & $34,45 \pm 8,70$ & 0,976 \\
\hline \multicolumn{7}{|l|}{ Yaşadığı yer } \\
\hline Kırsal & $36,01 \pm 7,66$ & $-0,035$ & $35,19 \pm 9,97$ & $-0,844$ & $35,19 \pm 8,64$ & $-0,556$ \\
\hline Kentsel & $36,18 \pm 7,88$ & 0,972 & $33,62 \pm 10,17$ & 0,399 & $34,07 \pm 9,34$ & 0,578 \\
\hline \multicolumn{7}{|l|}{ Kronik hastalık } \\
\hline Var & $33,68 \pm 8,95$ & $-1,437$ & $29,06 \pm 11,78$ & $-2,373$ & $31,31 \pm 9,82$ & $-2,105$ \\
\hline Yok & $36,34 \pm 8,00$ & 0,151 & $33,88 \pm 10,46$ & $0,018^{*}$ & $35,06 \pm 8,89$ & $0,035^{*}$ \\
\hline \multicolumn{7}{|l|}{ Sigara } \\
\hline Evet & $37,15 \pm 6,83$ & $-0,782$ & $33,41 \pm 10,70$ & $-0,832$ & $33,88 \pm 9,63$ & $-0,257$ \\
\hline Hayır & $35,68 \pm 8,21$ & 0,434 & $34,26 \pm 9,87$ & 0,406 & $34,55 \pm 8,98$ & 0,797 \\
\hline \multicolumn{7}{|l|}{ Egzersiz } \\
\hline Yetersiz & $36,14 \pm 7,79$ & $-0,420$ & $33,38 \pm 10,19$ & $-1,817$ & $33,87 \pm 9,35$ & $-1,206$ \\
\hline Yeterli & $36,16 \pm 7,97$ & 0,675 & $35,91 \pm 9,75$ & 0,069 & $35,85 \pm 8,49$ & 0,228 \\
\hline
\end{tabular}

${ }^{*} p<0.05,{ }^{* *} p<0.01,{ }^{* * *} p<0.001$

SOY puanları ve alt grup puanları yaş, BKi ve sağlık kuruluşuna başvuru sıklığı arasında ilişki incelendiğinde sağlık kuruluşuna başvuru sıklığı ile SOY puanı ve alt grup puanlarında arasında ilişki bulunmazken, yaş ve BKi ile SOY puanı ve alt grup puanlarında arasında negatif yönde zayıf düzeyde ilişki bulundu (SOY puanı ile sırasıyla $r=0,056 p=0,440 ; r=-0,291 p=<0,001 ; r=-0,194 p=0,005$ ) (Tablo 4).

Tablo 4. Sağlık okuryazarlığı korelasyon puanları

\begin{tabular}{lcccccc}
\hline & Tedavi ve hizmet alt grup puanı & $\begin{array}{c}\text { Hastalıklardan } \\
\text { korunma/sağlığın geliştirilmesi } \\
\text { alt grup puanı }\end{array}$ & \multicolumn{2}{c}{$\begin{array}{c}\text { Toplam sağlık okuryazarlık } \\
\text { puanı }\end{array}$} \\
Demografik veriler & $\begin{array}{c}\text { Korelasyon } \\
\text { katsayısı }\end{array}$ & $\mathbf{p}$ & $\begin{array}{c}\text { Korelasyon } \\
\text { katsayısı }\end{array}$ & $\mathbf{p}$ & $\begin{array}{c}\text { Korelasyon } \\
\text { katsayısı }\end{array}$ & p \\
\hline Yaş & $-0,269$ & $<0,001^{* * *}$ & $-0,267$ & $<0,001^{* * *}$ & $-0,291$ & $<0,001^{* * *}$ \\
$\begin{array}{l}\text { Beden kitle indeksi } \\
\text { Sağlık kurumuna }\end{array}$ & $-0,173$ & $0,012^{*}$ & $-0,190$ & $0,006^{* *}$ & $-0,194$ & $0,005^{* *}$ \\
başvuru sayısı & 0,033 & 0,646 & 0,019 & 0,803 & 0,056 & 0,440 \\
\hline${ }^{*} p<0.05, * * p<0.01, * * * p<0.001$ & & & & & &
\end{tabular}

\section{Tartışma}

Sağlık okuryazarlığı, bireylerin sağlıklı bir yaşam sürebilmesi için hastalıklardan korunma, hastalandıklarında uygun şekilde sağık bilgisine ulaşma sağlık durumlarını anlama ve bu bilgiler ışığında doğru tutum ve davranışları uygulayabilmeleri için oldukça hayatidir. Bu çalışmamızda polikliniğe başvuran hastaların sağık okuryazarlık düzeyi TSOY-32 ölçeğine göre; \%17,1'i yetersiz ve 28,9'u sorunlu sınırlı SOY olarak bulunmuştur. Sağlık bakanlığı tarafından ülke çapında yapılan Türkiye Sağlık Okuryazarlığı Düzeyi araştırmasında ülkemizde TSOY-32 ölçeğine göre kişilerin \%30,9'u yetersiz, \%38,0'i sorunlu-sınırlı SOY'a sahip olduğu belirtilmektedir. ${ }^{4}$ 
Yine ülkemizde yapılan diğer çalışmalarda da \%18,9- \%55,4 arasında yetersiz sağlık okuryazarlık düzeyi saptanmıştır. ${ }^{8-11}$ Ayrıca Avrupa Birliği Sağlık Okuryazarlığı Anketi (Health Literacy Survey European Union, HLSEN) ile Avrupa Birliği'ne üye olan sekiz ülkenin SOY düzeyini belirlemeye yönelik yapılan çalışmada, katılımcıların \%12'sinin yetersiz, \%47'sinin sınırlı SOY düzeyinde olduğu tespit edilmiştir. ${ }^{12}$ Yine Danimarka'da ülke çapında yapılan SOY düzeyi çalışmasında $\% 8,1$ yetersiz ve $\% 30,9$ u sorunlu SOY'a sahipti. ${ }^{13}$ Çalışmamızda yetersiz sağlık okuryazarlık düzeyi ülkemizde yapılan bazı çalışmalardan daha düşük ancak Avrupa da yapılan bazı çalışmalardan daha yüksek olarak bulunmuştur. ${ }^{8-13}$ Araştırma sonuçlarımıza göre SOY düzeyinin yüksek olmasının nedeni, hasta grubumuzda okuryazar olmayanların çalışmaya dahil edilmediği ve ilkokul mezunu oranının diğer çalışmalardan daha düşük olması ile ilişkilendirilebilir. Sonuç olarak eğitim düzeyinin sağlık okuryazarlığı üzeri olan olumlu etkisi olduğu literatür ile uyumludur. Özdemir ve arkadaşlarının çalışmasında da eğitim seviyesi sağlık okuryazarlığı ile ilişkili en önemli faktör olarak bulunmuştur. ${ }^{14}$

Katılımcılarımızın demografik özellikleri ve SOY düzeyleri arasında ilişkiler incelendiğinde bizim çalışmamıza benzer şekilde bazı çalışmalarda cinsiyetler ile SOY düzeyleri arasında farklılık gösterilememiştir. ${ }^{8,15}$ Ancak bizim çalışmamızdan farklı olarak bazı çalışmalarda erkeklerin SOY düzeylerini kadınlardan daha yüksek bulan çalışmalarda mevcuttur. ${ }^{4,9}$ SOY alt ölçekleri incelendiğinde Pınar ve arkadaşının çalışmasında alt ölçeklerde yine cinsiyetler arası fark gösterilemezken, çalışmamızda kadınların SOY alt ölçeklerinden hastalıklardan korunma ve sağlığın geliştirilmesi ile ilgili bilgiye ulaşma, bilgiyi anlama ve bilgiyi uygulama erkeklerden daha iyi olduğu gösterilmiştir. ${ }^{7}$

Eğitim açısından incelendiğinde, bu çalışmada eğitim düzeyi düşük olanlar daha fazla yetersiz sağlık okuryazarlık düzeylerine sahipti. Benzer şekilde literatürdeki çalışmalarda da düşük bir eğitim seviyesine sahip olmak sağlık bilgilerine erişim ve anlamak için, göreceli olarak düşük sağlık okuryazarlığı puanlarıyla önemli ölçüde ilişkili olduğu belirtilmektedir. ${ }^{12,16}$ Sağlık okuryazarlığı düzeyinin kişilerin eğitim durumundan etkilenmesi, eğitimin kişinin sağlığıyla ilgili durumlarda bilgiye ulaşma, anlama, değerlendirme süreçlerini kolaylaştıran ve sağlıkla ilgili davranışlara uyumu arttıran bir değişken olmasından kaynaklanabilir. ${ }^{11,14}$ Medeni durum açısından da Yakar ve arkadaşlarının çalışmasına benzer şekilde bekarlarda sağlık okuryazarlığı düzeyini yüksek saptamış. ${ }^{9}$ Bekarlarda sağlık okuryazarlığı düzeyinin yüksek saptanması çalışma grubumuzdaki bekarların eğitim düzeylerinin evli olanlardan daha iyi olması ve yine daha genç yaşta olması olabileceğini düşündürmüştür.

Sağlık ve beslenme okuryazarlığının iyileştirilmesi, insanların kendi sağlık durumlarını etkili bir şekilde uzun dönem kontrol edebilmesine imkan sağlar ve böylece sağlık ve sosyal bakım hizmetleri üzerindeki yükün azalabileceği düşünülür. ${ }^{17}$ Ayrıca SOY çocuk ve yetişkin popülasyonda ortaya çıkan obezite ve vücut kitle indeksi ile ilişkili olduğu belirtilmektedir. ${ }^{17,18}$ Bu çalışmada da zayıf ve normal vücut ağırlığına sahip olanların SOY puanları daha yüksek ve hastalıklardan korunma ve sağlı̆ı̆ı geliştirilmesi ile ilgili bilgiye ulaşma, bilgiyi anlama, bilgiyi değerlendirme ve bilgiyi uygulama fazla kilolu ve obezlerden yüksekti. Benzer şekilde Danimarka'da yapılan bir çalışmada da obezitesi olan bireylerde sağlık okuryazarlığı puanlarının önemli ölçüde daha yüksek olduğunu belirtilmektedir. ${ }^{13}$ Obezite ve obez insanların fazla vücut ağırlığını kaybetme veya normal kilo durumunu sürdürmedeki yetersizliğinin arkasındaki önemli bir nedenin düşük sağılk okuryazarlık düzeyleri olduğu belirtilmektedir. ${ }^{17,18}$ Hatta Düşük SOY'un obezitenin etiyolojiye rol oynayan etkenlerden olabileceğine dair kanıtlar vardır. ${ }^{17}$ Bu nedenle sağılık okuryazarlığı düzeylerini artırmak, dünya çapında obezite salgınını daha iyi yönetmede yararlı bir araç olabileceği düşünülmektedir. ${ }^{17,18}$

Yapılan bir çalışmada diyabet gibi kronik hastalıkları olan kişilerin kendi sağlık sorumlulukları alması gerektiği belirtilmektedir. ${ }^{19}$ Bireylerin kronik hastalıklarının takip ve tedavisinde görev almaları, kendi sağık durumlarını etkileyeceği için, SOY düzeyi düştükçe kronik hastalık artışlarının görülebileceği belirtilmektedir. ${ }^{4,20}$ Çalışmamızda kronik hastalık tanısı olanlarda, SOY puanı daha düşük saptanmıştır ve bu 
durum literatür verileri ile uyumlu bulunmuştur. ${ }^{8}$ Ayrıca kronik hastalık tanısı olmayanların hastalıklardan korunma/sağlığın geliştirilmesi alt ölçeğinde bilgiyi anlama, bilgiyi değerlendirme ve bilgiyi uygulamada kronik hastalık tanısı olanlardan daha yüksekti. Kronik hastalığa sahip kişiler sağlık sistemindeki hizmetlerden daha fazla yararlanmaya ihtiyaç duyan grubu oluşturmaktadır. Kronik hastalığı olan kişilerin SOY düzeylerinin yeterli olmaması, sağlık hizmetlerinden gerekli ölçüde yararlanamamalarına neden olabilmekte ve bu bireylerde hastalıklara bağlı gelişebilecek komplikasyonlar açısından geç kalınabilmektedir.

\section{Araştırmanın sınırlılıkları}

Çalışmamız tek bir ilde, tek merkezde ve az sayıda hasta ile yapılmış olduğundan tüm topluma genellenemez.

\section{Sonuç}

Araştırmamızdan elde edilen veriler sonucunda, sağlık okuryazarlık düzeyleri lise ve üzeri eğitimi olan kişilerde, lise altı eğitimi olanlara göre daha yüksekti. Bununla birlikte çalışma grubumuzda bekar olan kişilerin eğitim düzeyleri evli olanlardan daha yüksek olduğundan sağlık okuryazarlık düzeyleri de daha yüksek olarak bulundu. Ayrıca zayıf- normal kilolu olanlarda fazla kilolu ve obez olanlara göre SOY düzeyleri daha yüksekti. Sağlık okuryazarlık puanı açısından ise, kadınların erkekler göre, zayıf ve normal kilolu olanların fazla kilolu ve obez olanlara göre, bekarların evlileri göre, lise ve üzeri eğitimi olanların lise altı eğitimi olanlara göre ve kronik hastalık tanısı olmayanlarda kronik hastalık tanısı olanlara göre toplam puan ortalaması daha yüksekti.

Kişilerin SOY düzeyleri ve SOY puanları eğitim seviyeleri başta olmak üzere bazı değişkenlerden etkilendiği gösterilmiştir. Bu risk faktörleri göz önünde bulundurularak SOY düzeylerinin arttırılması, toplum sağlığının geliştirilmesi açısından büyük önem arz etmektedir. Düşük SOY seviyesi bireylerin sağlık hizmetinden faydalanmasının önündeki kendilerinden kaynaklı önemli bir engeldir. Bu sebeple toplumun sağılk okuryazarlık düzeyini arttıracak sağlık eğitimlerinin çocukluk çağından itibaren verilmesi, eğitim kurumlarındaki müfredat programlarında bu yönde düzenlemeler yapılması ve bunların tüm eğitim kurumlarını içerecek biçimde standartlaştırılması sağlık okuryazarlığının geliştirilmesinde katkı sağlayabilir.

\section{Bilgi}

Çıkar çatışması bulunmamaktadır. Yazarlar herhangi bir finansal destek bildirmemişlerdir. Makale 17. Aile Hekimliği Araştırma Günleri'nde (08-10 Nisan 2021) Online sözlü bildiri olarak sunulmuştur.

\section{Etik Onay}

Pamukkale Üniversitesi Tıp Fakültesi Girişimsel Olmayan Klinik Araştırmalar Etik Kurulu'ndan izin alınmıştır (Karar tarihi - sayı: 17/03/2020 - 06).

\section{Araştırmacı Katkı Oranı Beyanı}

Nilüfer Emre: Fikir, tasarım, danışmanlık/denetleme, analiz ve yorum, kaynak taraması, makale yazımı, eleştirel inceleme.

Mehmet Arslan: Veri toplama ve işleme, analiz ve yorum, kaynak taraması, makale yazımı, eleştirel inceleme. Tamer Edirne: Danışmanlık/denetleme, eleştirel inceleme.

Aysun Özşahin: Fikir, eleştirel inceleme.

Aylin Çiğdem: Tasarım, veri toplama ve işleme, eleştirel inceleme.

\section{Kaynaklar}

1. Network of the National Library of Medicine (NNLM) [internet] Health Literacy [cited 2021 May 5]. Available from: https://nnlm.gov/initiatives/topics/health-literacy.

2. World Health Organization. [internet] Health Literacy [cited 2021 May 5]. Available from: https://www.who.int/healthpromotion/health-literacy/en/. 
3. Madeeha M, Rubab ZZ, Azhar H. Health Literacy as a Global Public Health Concern: A Systematic Review. J of Pharmacol \& Clin Res 2017; 4(2): 555632.

4. Sağlık Bakanlığı [Internet]. Türkiye sağlık okuryazarlığı düzeyi ve ilişkili faktörlerin araştırılması [cited 2021 May 1] Available from: https://sggm.saglik.gov.tr/Eklenti/39699/0/soya-rapor-1pdf.pdf

5. Kickbusch I. Health literacy: an essential skill for the twenty-first century. Health Educ 2008;108:101-104.

6. Tözün M, Sözmen MK. Halk sağlığı bakışı ile sağlık okuryazarlığı health Literacy with Perspective of Public Health. Smyrna Tıp Dergisi 2015;2:48-54.

7. Okyay P, Abacıgil F. Türkiye sağlik okuryazarliği ölçekleri güvenilirlik ve geçerlilik çalışması. T.C. Sağlık Bakanlığı [internet] [cited 2021 May 1] Available from:

https://sbu.saglik.gov.tr/Ekutuphane/kitaplar/Sa\%C4\%9FI\%C4\%B1k\%200kur\%20Yazarl\%C4\%B1\%C4\%9F\%C4\%B1.pdf

8. İkiışık $H$, et al. Üçüncü Basamak Sağlık Kuruluşuna Başvuran Hastaların Sağlık Okuryazarlığı Düzeyinin İncelenmesi. Ankara Üniversitesi Tıp Fakültesi Mecmuası 2020;73(3):247-52.

9.Yakar B, Gömleksiz M, Pirinççi E. Bir Üniversite Hastanesi Polikliniğine Başvuran Hastaların Sağlık Okuryazarlığı Düzeyleri ve Etkileyen Faktörler. Euras J Fam Med 2019;8(1):27-35.

10. Berberoğlu U, et al. Bir Aile Sağlığı Merkezine Kayıtlı 18-65 Yaş Grubu Bireylerdeki Sağlık Okuryazarlığı Durumunun Değerlendirilmesi. Sakarya Med J 2018;8(3):575-81.

11. Bakan AB, Yildiz M. 21-64 Yaş Grubundaki Bireylerin Sağlık Okuryazarlık Düzeylerinin Belirlenmesine illişkin Bir Çalışma. Sağlık ve Toplum 2019;8 33-44.

12. Sørensen K, et al. Health literacy in Europe: comparative results of the European health literacy survey (HLS-EU). Eur J Public Health 2015;25(6):1053-8.

13. Svendsen MT, et al. Associations of health literacy with socioeconomic position, health risk behavior, and health status: A large national population-based survey among Danish adults. BMC Public Health 2020;20:1-12.

14. Ozdemir H, et al. Health literacy among adults: a study from Turkey. Health Educ Res 2010;25(3):464-77.

15. Değerli H, Tüfekçi N. Toplumun sağlık okuryazarlık düzeyinin belirlenmesi. Avrasya Uluslararası Araştırmalar Dergisi 2018; 6(15): 467-488.

16. Heide IVD, et al. Health literacy of Dutch adults: a cross sectional survey. BMC Public Health 2013;13:179.

17. Michou M, Panagiotakos DB, Costarelli V. Low health literacy and excess body weight: a systematic review. Cent Eur J Public Health 2018;26(3):234-241.

18. Chrissini MK, Panagiotakos DB. Health literacy as a determinant of childhood and adult obesity: a systematic review. Int J Adolesc Med Health 2021;33(3):9-39.

19. Takcı MA, Yıldııım G. Diyabet Hastalarına Sağlık İnanç Modeli Doğrultusunda Verilen Eğitimin Sağlık İnancına, Öz Etkililik Algısına ve Karar Verme Düzeyine Etkisi. Mersin Üniversitesi Tıp Fakültesi Lokman Hekim Tıp Tarihi ve Folklorik Tıp Dergisi 2021;11(1): 73-82. 20. Gücük S, Dilekçi E, Kayhan M. Kas iskelet sistemi şikayetleriyle yatan hastaların sağlık okuryazarlığı ve birinci basamak sağlık hizmetlerini kullanma durumları. Euras J Fam Med 2020;9(3):131-8. 